\title{
Integration of Athletics and Academics: Survey of Best Practices at FBS Schools
}

\author{
John Spicer Nichols, Thomas F. Corrigan, and Marie Hardin \\ Penn State University in collaboration \\ with the Coalition on Intercollegiate Athletics
}

\begin{abstract}
The Coalition on Intercollegiate Athletics (COIA), an alliance of 57 university faculty senates, was founded in 2002 to provide a faculty voice in the national discussion about how to best maintain academic integrity in big-time college sports. COIA's most recent white paper, Framing the Future: Reforming Intercollegiate Athletics (2007), proposes best practices for individual universities to help ensure that college sports are more fully integrated into their academic goals, values and missions. Reported here are the results of a national survey that gauged the extent to which COIA's best practices have been adopted by schools participating in the Football Bowl Subdivision. The findings suggest that big-time athletics programs have a number of underutilized tools at their disposal that can assist them in protecting core academic values and standards at universities competing at the highest level of intercollegiate sport.
\end{abstract}

"(I)ntercollegiate athletics, while providing positive benefits to athletes, the campus and the broader community, at times clashes with the educational goals and mission of our institutions. These conflicts, which by many measures are on the increase, have the potential of undermining the values and aims of higher education" (COIA, 2007, p. 2).

Those words are from a report by the Coalition on Intercollegiate Athletics (COIA), an alliance of 57 university faculty senates founded in 2002 to provide a faculty voice in the national discussion about how to best maintain academic integrity in big-time college sports. COIA represents member senates at universities participating in the Football Bowl Subdivision (FBS), formerly Division 1A of the National Collegiate Athletic Association (NCAA), and aims to engage faculty with issues of intercollegiate athletic reform and share ideas on how reforms can be implemented at their institutions.

Since its founding, COIA has produced several policy papers and reports to intercollegiate athletic reform groups such as the NCAA Presidential Task Force and Knight Commission on Intercollegiate Athletics. The late NCAA President Myles Brand, who placed academic reform of intercollegiate athletics

Nichols is a professor emeritus, Corrigan is a $\mathrm{PhD}$ candidate, and Hardin is an associate professor, at John Curley Center for Sports Journalism, College of Communications, Penn State University, University Park, PA. 
high on the association's agenda, encouraged the creation of COIA, collaborated with its leadership, and endorsed its general approach-if not all of its specific recommendations-of identifying "best practices" that individual universities might adopt to better protect "the principle that academic achievement and participation in athletics are not in conflict." He concluded, "The totality of the COIA recommendations represents a significant effort for a group critical to the success of the reform movement" (Brand, 2005). New NCAA President Mark A. Emmert has indicated that maintaining academic standards for athletes would remain high on the NCAA agenda under his leadership (Sander, 2010).

COIA's most recent white paper, Framing the Future: Reforming Intercollegiate Athletics (2007), identifies major challenges confronting intercollegiate athletics and proposes best practices that individual universities might adopt to help ensure that college sports are more fully integrated into their academic goals, values and missions and remain a positive force on their campuses. The proposals-some drawn from previous COIA reports, others newly developed-fell into four areas of concern: academic integrity and quality, student-athlete welfare, campus governance of intercollegiate athletics, and fiscal responsibility.

Framing the Future was formally approved by a vote of the COIA members and promulgated in 2007 after a lengthy and inclusive deliberative process. The initial draft was written by the COIA steering committee, cochaired by Professors Nathan Tublitz of the University of Oregon and Virginia L. Shepherd of Vanderbilt University, in consultation with the NCAA leadership. Subsequent drafts were shared with the Association of Governing Boards, Faculty Athletics Representatives Association, Division IA Athletics Directors Association, Division IA Faculty Athletics Representatives, American Association of University Professors, College Sports Project, National Association of Athletic Academic Advisors, Knight Commission, and NCAA, and many of their suggestions were incorporated in the final draft.

\section{Purpose of the Survey and Research Questions}

In 2008, the John Curley Center for Sports Journalism at the Penn State College of Communications - in partnership with COIA - launched a research project intended to assess the extent to which the best practices in Framing the Future were implemented at FBS schools. COIA had invested a significant amount of time and effort to develop its recommendations for integrating intercollegiate athletics more fully into the academic mission of universities but had no hard evidence of the extent to which they were adopted and actually had positive benefit at the local level. A national survey of FBS schools would be the first step in such an assessment. Furthermore, benchmarking data would allow individual universities to compare their practices of athletic-academic integration with those of peer institutions. Such self-assessment could provoke internal discussions about what might be done at the local level to foster improvement. A final goal was to identify those universities that have effectively implemented COIA best practices, to conduct detailed case studies seeking to better understand their local application, and to acknowledge (with permission) their relative success in athletic-academic integration. It is important to note that the goal was not to be prescriptive. A major theme in Framing the Future and other COIA policy papers is the belief that best 
practices vary widely across institutions and that a one-size-fits-all approach would not work for all FBS schools.

The following research questions were proposed for this study:

1) To what extent have FBS schools implemented COIA best practices regarding athletic-academic integration?

2) What FBS schools have effectively implemented COIA best practices, and what are the local circumstances that help to explain that success?

The second research question will be considered in a companion article in this issue of the Journal of Intercollegiate Sport.

\section{Method}

The COIA steering committee, after discussion with the membership at a national meeting, selected 20 best practices-primarily from Framing the Future and its other policy papers-that best gauged the Coalition's emphasis on the primacy of academics in intercollegiate athletics and on transparency and accountability in the conduct and governance of athletic programs. The Curley Center then operationalized those best practices into a survey instrument. (Discussion of the weight of each item and the scoring system for reassembling the survey items into the original COIA best practices appears in the companion article.)

Next, the Curley Center sought input from an ad hoc panel of experts and incorporated their feedback into the final draft of the survey instrument. Members of expert panel were William Anderson of Michigan State University, Billy Hawkins of the University of Georgia, Scott Kretchmar of Penn State University, Robert Malekoff of Guilford College, and Allen Sacks of University of New Haven. And, finally, the survey instrument was pretested with 12 FBS schools. Telephone debriefings were conducted with those who completed the draft survey, and very minor adjustments were made to the survey. The changes were minor enough to allow the pretest schools to be folded into the larger pool of respondents.

In July 2009, the surveys were mailed to the chair or president of the faculty governance body (or the closest equivalent) at all 120 FBS institutions. The chairs or presidents were encouraged to consult with the institution's Faculty Athletics Representative (FAR) or the chair of the Campus Athletic Board-those most likely to be familiar with the items addressed in the survey. The respondents were informed that only aggregate data would be reported and that individual universities would not be identified without their permission.

Five FBS institutions do not have faculty governance bodies, and, thus, were removed from calculation of the response rate. Sixty-one of the remaining 115 FBS institutions completed and returned the survey for a 53\% response rate. This is a respectable response rate, especially for a mail survey of considerable length and complexity.

By directly contacting university officials and independently checking publicly available information about athletic programs, the researchers sought to verify the responses to selected survey questions. These checks indicated that the survey respondents reported accurately and, therefore, the data summarized below are reflective of actual university practices in 2008-2009, the academic year studied. 
Of the 61 institutions that responded to the survey and were included in this analysis, 39 (63.9\%) were COIA-affiliated. Eleven conferences were represented. The responses came from 4 institutions in the Atlantic Coast Conference, 7 in the Big-12 Conference, 4 in the Big East Conference, 9 in the Big Ten Conference, 8 in Conference USA, 5 in Mid-American Conference, 3 in Mountain West Conference, 5 in the Pacific-10 Conference, 9 in the Southeastern Conference, 4 in the Sun Belt Conference, and 3 in the Western Athletic Conference. Fifty-three $(86.9 \%)$ of the institutions that responded were public and 8 were private. Thirty-eight $(62.3 \%)$ of the responding institutions were participants in Bowl Championship Series (BCS) conferences and 23 were not.

FBS schools that participated in the survey did not differ significantly from nonparticipants in terms of conference membership, public or private status, or whether the school competes in a BCS conference. COIA affiliation was significantly related to participation in the survey, $\mathrm{X}^{2}(1)=19.66, p<.001$; however, only one survey question (D5c regarding whether the chair of the Campus Athletic Board reported in person to the faculty governance body) produced statistically significant different answers between COIA members and nonmembers, $\mathrm{X}^{2}(1)=$ $5.07, p<.05$. In other words, the results of the survey have considerable external validity and can be reasonably generalized to all FBS schools.

\section{Results}

The survey results indicate that most FBS schools have not implemented most COIA best practices for academic integration of intercollegiate athletics. There was some variability in practices among universities depending on their conference membership, public/private status, or whether they were BCS participants, but most universities appear to have considerable latitude for adopting-if locally appropriate-additional practices that might improve the transparency and accountability of intercollegiate athletics and protect the primacy of academics on their campuses.

A comparison of COIA best practices in eight areas (admissions and recruiting, academics, student-athlete integration, campus governance of athletics, scholarships, governance aspects of fiscal matters, student-athlete welfare, academic advising) and actual practices by FBS schools follows. ${ }^{1}$

\section{Admissions and Recruiting}

As a general proposition, "student-athletes should be admitted based on their potential for academic success and not primarily on their athletic contribution to the institution" (COIA, 2007, p.7). They should not be admitted if they cannot perform academically at a university level or do not have a good prospect of earning a degree. Consequently, the academic profiles of entering student-athletes should be similar to those of nonathletes, and any special admissions of student-athletes should be in accordance with the same standards applied to nonathletes. To achieve these goals, faculty and academic administrators should be integrally involved in the admissions of student-athletes.

COIA Best Practice: "General admissions policies should be the same for all students, student-athletes and non-student-athletes" (COIA, 2007, p.7). Survey Result: The admission of student-athletes was integrated into the existing admis- 
sions process at nearly all FBS universities and was subject to the same admissions policies for nonathletes at a large majority of them (Tables A1 and A2).

COIA Best Practice: "Data on the academic profiles of entering studentathletes and non-student-athletes should be reviewed at least annually by the Campus Athletics Board or the campus faculty governance body... Data on the academic performance of student-athlete special admits should be reviewed at least annually by the Campus Athletic Board or the campus faculty governance body" (COIA, 2007, p.7). Survey Results: A large majority of faculty governance bodies at FBS schools did not review academic profiles of entering student-athletes and the academic performance of student-athlete special admits during 2008-2009, the year of

\section{Table A}

\begin{tabular}{ll}
\hline Admissions and Recruiting & $\%(\mathbf{n})$ \\
\hline 1. The admissions process for student-athletes & \\
a. is integrated into the university's existing (non-student-athlete) & $95.1(58)$ \\
$\quad$ admission services office. & \\
b. is under the purview of admissions officers in the existing admissions & \\
$\quad$ office. & $96.7(59)$
\end{tabular}

2. Admissions applications from athletes are subject to the same admissions policies as those from non-athletes.

3. Comprehensive data on the academic profiles

a. of all entering student-athletes were reviewed during the 2008-2009 academic year by

i. the campus faculty governance body.

ii. the Campus Athletics Board.

b. of all entering non-student-athletes were reviewed during the 2008-2009 academic year by

i. the campus faculty governance body.

ii. the Campus Athletics Board.

4. Data on the academic performance of student-athlete special admits were reviewed during the 2008-2009 academic year by

a. the campus faculty governance body.

b. the Campus Athletics Board. $64.6(31)^{\mathrm{iii}}$

5. The recruiting processes for student athletes were reviewed during the 2008-2009 academic year by

a. the campus faculty governance body.

b. the Campus Athletics Board.

c. the Faculty Athletics Representative.

$73.3(44)^{\mathrm{i}}$

\footnotetext{
i $1.6(1)$ missing

ii 13.1(8) N/A; 3.3(2) missing

iii $13.1(8) \mathrm{N} / \mathrm{A} ; 8.2(5)$ missing

iv $3.3(2)$ missing
} 
study; however, nearly a majority of Campus Athletic Boards reviewed academic profiles of entering student-athletes and nearly two-thirds reviewed the aggregate academic performance of student-athlete special admits (Table A3 and A4).

COIA Best Practice: "Faculty should be involved in developing and overseeing campus policies regarding recruiting of student athletes" (COIA, 2007, p.7). Survey Results: Nearly three-quarters of the faculty athletic representatives, nearly half of the Campus Athletic Boards, but less than one in five faculty governance bodies at FBS schools reviewed the student-athlete recruiting process during the previous year (Table A5).

\section{Academics}

A core principle of intercollegiate athletics is that student-athletes should be held to the same academic standards as all other students at their universities. To that end, "(n)o academic programs or majors should be designed specifically for studentathletes or created for the purpose of allowing student-athletes to maintain their eligibility. Qualified student-athletes should be allowed and in fact encouraged to pursue the major of their choice and to have the same access to academic classes and programs as other students without explicit or implicit athletic consequences" (COIA, 2007, p.8).

COIA Best Practice: "Data on student-athletes' choice of major should be gathered and evaluated by the campus faculty governance body or the Campus Athletic Board... To preserve academic integrity, the campus faculty governance body or the Campus Athletic Board should monitor student-athlete enrollment by course... Academic Progress Rate (APR), Graduation Success Rate (GSR) and other available graduation rate data should be reviewed annually by the campus faculty governance body to sustain processes that will improve the academic success and graduation rates of student-athletes" (COIA, 2007, p.8). Survey Results: Data on student-athletes' choice of major and courses and their grades were not reviewed in 2008-2009 by a large majority of faculty governance bodies at FBS schools. A majority of Campus Athletic Boards reviewed student-athletes' majors and grades but not courses (Tables B1, B2 and B3). Almost all Campus Athletic Boards and about two-thirds of faculty governance bodies annually reviewed Federal Graduation Rates, Graduation Success Rates, and Academic Progress Rates for all sports (Table B4 and B5).

\section{Student-Athlete Integration}

Student-athletes should be mainstreamed into the academic life of their universities, and notwithstanding the substantial time demands of athletic competition, they should not be disadvantaged in their educational pursuits and generally have the same academic opportunities as nonathletes.

COIA Best Practice: "Individual athletic competitions and associated travel should be scheduled to minimize lost class time. Institutional policies designed to minimize lost class time should be described... Athletically related activities (e.g., formal and informal practices, team meetings, and any activities at which the attendance of student-athletes is required) should be scheduled outside the prime times for academic classes. Each institution should explain how it achieves this scheduling goal" (COIA, 2007, p. 9). Survey Results: A large majority of FBS 


\section{Table B}

\begin{tabular}{lc}
\hline Academics & $\%(\mathbf{n})$ \\
\hline 1. By sport, data on student-athletes' choice of major were reviewed during the \\
2008-2009 academic year by \\
$\begin{array}{ll}\text { a. the campus faculty governance body. } & 26.2(16) \\
\text { b. the Campus Athletics Board. } & 57.4(35)\end{array}$
\end{tabular}

2. The following, reported by sport, were reviewed during the 2008-2009 academic year by the campus faculty governance body:
a. student-athletes' courses
b. student-athletes' sections
c. student-athletes' grades

3. The following, reported by sport, were reviewed during the 2008-2009 academic year by the Campus Athletics Board:
a. student-athletes' courses
b. student-athletes' sections
c. student-athletes' grades

4. The following, reported by sport, were reviewed during the 2008-2009 academic year by the campus faculty governance body:
a. Federal Graduation Rate
b. Graduation Success Rate
c. Academic Progress Rate
$65.6(40)$

5. The following, reported by sport, were reviewed during the 2008-2009 academic year by the Campus Athletics Board:
a. Federal Graduation Rate
$90.0(54)^{\mathrm{ii}}$
b. Graduation Success Rate
$93.3(56)^{\mathrm{ii}}$
c. Academic Progress Rate
$93.3(56)^{\mathrm{ii}}$

${ }^{\mathrm{i}} 1.6(1)$ missing

ii $3.3(2)$ missing

universities had a written policy for scheduling travel and athletic competition focusing on minimizing lost class time, and a much smaller majority have written policies for scheduling athletically related on-campus events, such as practices, aimed at minimizing conflict with prime times for academic classes. For a majority of the schools, their policies were publicly accessible and reviewed by the faculty governance body or the campus athletic board in 2008-2009 (Tables C1 and C2).

\section{Campus Governance of Athletics}

COIA Best Practice: "A majority of (Campus Athletic Board) members should be tenured faculty who should be appointed or elected through rules established by the campus faculty governance body. The Faculty Athletic Representative should be an ex officio voting or non-voting member of the Board" (COIA, 2007, p. 11). 


\section{Table C}

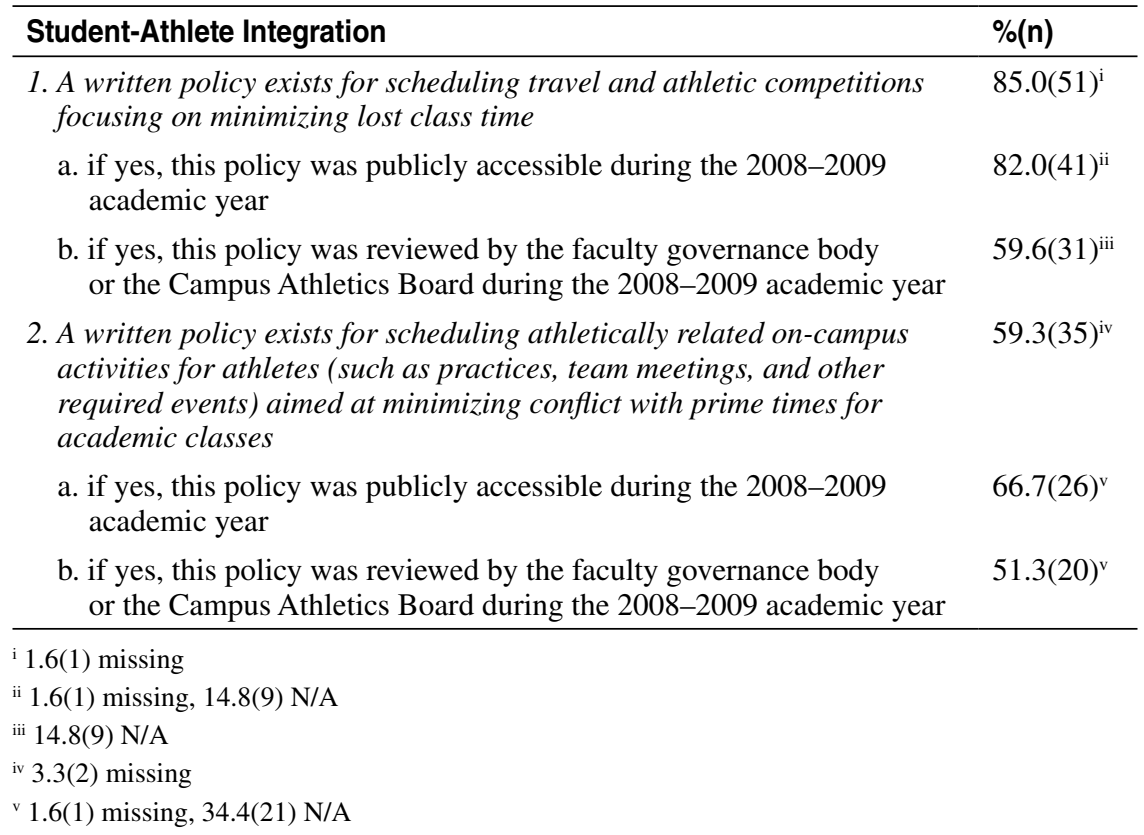

Survey Results: The majority of Campus Athletic Boards at FBS schools were not standing committees of the faculty governance body. However, four-fifths of the boards had a majority of tenured faculty as voting members, and nearly the same percent of boards had at least one faculty representative elected or appointed by the faculty governance body. Nearly all Faculty Athletics Representatives were members of the Campus Athletic Board. Membership of the board and contact information for the members were publicly accessible in 2008-2009 at the vast majority of FBS schools (Tables D1 and D2).

COIA Best Practice: "Major athletic department decisions (e.g., hiring of the athletic director and key athletic department personnel, changes in the total number of intercollegiate sports, initiation of major capital projects, etc.) should be made in consultation with the Campus Athletic Board and leaders of the campus faculty governance body and appropriate faculty committee(s)" (COIA, 2007, p. 11). Survey Results: A small minority of faculty governance leaders, nearly half of the Campus Athletic Boards, and more than two-thirds of Faculty Athletic Representatives at FBS schools were consulted before major athletic decisions (Table D3).

COIA Best Practice: "The Faculty Athletic Representative... should be appointed by the University President based on recommendation by the campus faculty governance body" (COIA, 2007, p. 11). Survey Results: A slim majority of Faculty Athletic Representatives were appointed by the university president after consultation with and approval of the campus faculty governance body (Table D4).

COIA Best Practice: "The Athletic Director, Faculty Athletic Representative and the Campus Athletic Board chair should report orally and in writing at least once a year to the campus faculty governance body. Their reports should include 


\section{Table D}

\section{Campus Governance of Athletics \\ 1. The Campus Athletic Board \\ a. is a standing committee or subcommittee of the faculty governance body \\ b. includes the Faculty Athletics Representative as an ex officio voting or non-voting member \\ c. has a voting component that consists of a majority of tenured faculty members \\ d. has a voting component that includes at least one faculty member elected or appointed directly by the campus faculty governance body}

$\%(\mathbf{n})$

$42.4(25)^{\mathrm{i}}$

2. Membership on the Campus Athletics Board, including contact information for each member, was publicly accessible during the 2008-2009 academic year

3. Before all major athletic decisions (e.g., hiring of key personnel, changes in sports, initiation of capital projects, etc.), the following are consulted:

a. the leaders of the campus faculty governance body

b. the Campus Athletics Board

c. the Faculty Athletics Representative

4. The current Faculty Athletics Representative was appointed by the University President after consultation with and approval of the campus faculty governance body

5. Each of the following made a report, in person, to the full membership of the campus faculty governance body during the 2008-2009 academic year:

a. the Faculty Athletics Representative

b. the Athletic Director

c. the chair of the Campus Athletics Board

6. Each of the following made a report, in writing, to the full membership of the campus faculty governance body during the 2008-2009 academic year:

a. the Faculty Athletics Representative

b. the Athletic Director

c. the chair of the Campus Athletics Board

\footnotetext{
i 3.3(2) missing

ii $1.6(1)$ missing

iii 4.9(3) missing
} 
a focus on academic benchmarks including the APR, GSR, graduation rates and the percentage and progress of student athlete special admits" (COIA, 2007, p. 11). Survey Results: A slim majority of Faculty Athletic Representatives, Athletic Directors, and Campus Athletic Board chairs at FBS schools reported in person to the full membership of the faculty governance body in 2008-2009, and only small minorities of them did so in writing (Tables D5 and D6).

\section{Scholarships}

COIA believes there should be a presumption that athletic scholarships will be renewed for five years (or until graduation) for student-athletes who are in good academic standing, obey team rules, and conform to both athletic department and general campus codes of conduct.

COIA Best Practice: "Institutions should establish criteria and a mechanism for revoking a scholarship. The final authority for revoking a scholarship should rest with the campus' chief financial aid officer or with the chief academic officer", (COIA, 2007, p. 9). Survey Results: The final authority of revoking an athletic scholarship rested with the provost or the chief financial aid officer at a solid majority of FBS universities in 2008-2009. Three-quarters of Faculty Athletics Representatives, but only a small percentage of Campus Athletic Boards or faculty governance bodies, reviewed scholarship terminations to ensure their accordance with NCAA and campus procedures (Tables E1 and E2).

\section{Governance Aspects of Fiscal Matters}

Athletic budgets should be transparent and aligned with the mission, goals and values of the academic institution.

COIA Best Practice: "The University President should take the lead to ensure that fiscal reports... are issued annually and made available to the campus faculty

\section{Table E}

\begin{tabular}{ll}
\hline Scholarships & $\%(\mathbf{n})$ \\
\hline $\begin{array}{l}\text { 1. University policy stipulates that final authority for revoking an athletic } \\
\text { scholarship rests with either the Provost or the campus chief financial } \\
\text { aid officer }\end{array}$ & $61.4(35)$ \\
a. if yes, such authority was communicated in writing to all student- & $80.5(33)^{\mathrm{i}}$ \\
athletes during the 2008-2009 academic year & \\
2. To ensure their accordance with NCAA and campus procedure, \\
scholarship terminations were reviewed during the 2008-2009 \\
$\begin{array}{l}\text { academic year by } \\
\text { a. the faculty governance body }\end{array}$ \\
$\begin{array}{l}\text { b. the Campus Athletics Board } \\
\text { c. the Faculty Athletics Representative }\end{array}$ \\
\hline
\end{tabular}

i $23.0(14)$ N/A; 9.8(6) missing

ii $8.2(5) \mathrm{N} / \mathrm{A} ; 3.3(2)$ missing

iii 8.2(5) N/A; 6.6(4) missing 


\section{Table F}

\begin{tabular}{ll}
\hline Governance Aspects of Fiscal Matters & $\%(\mathbf{n})$ \\
\hline $\begin{array}{l}\text { 1. The faculty governance body has been provided, on a regular basis, } a \\
\text { thorough financial accounting of athletics during the athletics budget } \\
\text { construction or review process }\end{array}$ & $36.7(22)^{\mathrm{i}}$ \\
$\begin{array}{l}\text { 2. University policy stipulates that the faculty governance body be } \\
\text { consulted regarding fiscal transfers to Athletics from the institution's } \\
\text { General Fund }\end{array}$ & $18.0(11)^{\mathrm{ii}}$ \\
3. Transfers to Athletics from the institution's General Fund during the & $21.2(7)^{\mathrm{i}}$ \\
2008-2009 academic year were completed in consultation with the & \\
faculty governance body & \\
i $6.6(4)$ missing & \\
ii $3.3(2)$ missing &
\end{tabular}

governance body. The President should work closely with faculty leaders, existing faculty committees, and athletic department personnel to achieve these goals" (COIA, 2007, p. 12). Survey Results: Only a small minority of faculty governance bodies were provided financial accounting of athletic budget construction or were consulted regarding fiscal transfers from the institution's general funds to athletics (Table F).

\section{Student-Athlete Welfare}

Although Framing the Future did not include specific best practices in this area, student-athlete welfare underlies much of COIA's views on the integration of athletics and academics, and the COIA members who drafted the survey criteria proposed the addition of a question to determine if institutions regularly assessed student-athlete well-being. Survey Results: Nearly four-fifths of FBS institutions assessed student-athlete well-being in the previous year; however, only a slight majority of those assessments were independent of the athletic department (Table G).

\section{Academic Advising}

As a specific and important means of protecting academic primacy in intercollegiate athletics, COIA has long emphasized that "academic advising and academic support for student-athletes should be structured to give student-athletes as valuable

\section{Table G}

\begin{tabular}{ll}
\hline Student-Athlete Welfare & $\%(\mathbf{n})$ \\
\hline $\begin{array}{l}\text { 1. The institution assessed student-athlete well-being during the } \\
\text { 2008-2009 academic year. }\end{array}$ & $78.7(48)$ \\
a. if yes, this assessment used a process independent of the Athletics & $63.0(34)^{\mathrm{i}}$ \\
Department &
\end{tabular}

i 11.5(7) missing 


\section{Table H}

\begin{tabular}{|c|c|}
\hline \multicolumn{2}{|l|}{ Academic Advising } \\
\hline \multicolumn{2}{|l|}{ 1. Athletic academic advisers } \\
\hline a. are appointed by the cam0pus academic advising services structure & $35.0(21)^{\mathrm{i}}$ \\
\hline $\begin{array}{l}\text { b. have a direct reporting line to the campus academic advising services } \\
\text { structure }\end{array}$ & $58.3(35)^{\mathrm{i}}$ \\
\hline
\end{tabular}

i (1.6(1) missing

and meaningful an educational experience as possible and not just to maintain their athletic eligibility."

COIA Best Practice: "The academic advising facility for student-athletes should be integrated into and report through the existing academic advising structure and not through the Athletics Department... The campus academic advising structure or the office of the chief academic officer should have oversight of and regularly review the academic advising of student-athletes... Athletic academic advisors should be appointed by and work for the campus academic advising structure and not solely for the Athletics Department" (COIA, 2007, p. 10). Survey Results: Slightly more than one-third of athletic academic advisers were appointed by-but a majority report to- the campus academic advising services structure (Table $\mathrm{H}$ ).

For a few of the COIA best practices in the eight areas discussed above, there were significant differences in responses among institutions according to their conference membership, public/private status, and BCS participation. However, because the cell counts were frequently too small to warrant confident interpretation and because no meaningful patterns were noted among the differences, these data are not reported here.

\section{Discussion}

Many of those concerned about the problems facing intercollegiate athletics suggest that individual universities may be incapable of protecting the academic integrity of their athletic programs against an onslaught of powerful external forces, such as the commercial pressures of television and the demands of the sports-obsessed American culture. They argue that, because the problems are primarily structural, they must be solved at the national level by the NCAA or through government regulation. FBS university presidents reinforced this view in their responses to a recent confidential survey conducted by the Knight Commission on Intercollegiate Athletics about the spiraling costs of athletic programs and the fallout on the academic mission. Although they said that major changes are needed in big-time college sports, the university presidents "believe they have limited power to effect change on their own campuses regarding athletics financing and the larger problems it has created." Noting a "disturbing and growing cultural divide between academics and athletics," the presidents lamented "the negative impact big-time intercollegiate athletics can have on the larger mission and values of higher education and its potential divisiveness within the university community" (Knight Commission, 2009, p. 16, 31-32). 
Regardless of whether such calls for systematic national reform of intercollegiate athletics are legitimate, the data from this survey strongly suggest that individual universities still have plenty of room for internal improvements in their athletic programs. Most FBS schools have at their disposal an array of unused tools that could be employed-depending on the local culture and circumstances - to enhance the transparency and accountability of their athletic programs and strengthen their academic standards.

Not surprisingly, the Coalition on Intercollegiate Athletics-as an alliance of university faculty senates-places great emphasis on the role of the faculty in the survival of the collegiate athletic model. The faculty are the guardians of academic values and standards at their universities and, in the opinion of COIA, should not abrogate that responsibility in regard to intercollegiate athletics. Yet, widespread indifference, dissatisfaction, and misunderstanding regarding intercollegiate athletics seem to prevail among the faculty at most universities (Lawrence, Hendricks, \& Ott, 2007).

The results of this survey indicate that only a minority of faculty governance bodies at universities with big-time athletic programs exercised direct oversight in important academic matters related to student-athletes, such as admissions, scholarships, advising, and integrity of majors and courses. To the extent that faculty were involved in the oversight and governance of intercollegiate athletics, these functions tended to fall to the Faculty Athletics Representative and, secondarily, the Campus Athletic Board. The NCAA requires that the FAR at all of its member institutions must hold faculty rank and not be an administrator or coach and that the CAB must have a voting majority of full-time academic administrators and regular faculty, but beyond those stipulations, the NCAA allows wide latitude at the university level in the appointment and responsibilities of faculty in athletics governance. The data indicate that most of the key academic oversight responsibilities were centralized with the FAR. As previously noted (see Table D), FARs were consulted before major athletic decisions at more than two-thirds of FBS schools, compared with less than one-fifth for faculty governance bodies and less than half CABs. But, notwithstanding the FARs' importance as the faculty voice in the operation of intercollegiate athletics, a bare majority was appointed after consultation with and approval of the faculty governance body at FBS schools.

The Campus Athletic Boards also have far greater oversight responsibilities in the realm of intercollegiate athletics than the faculty governance bodies. On almost all academic-athletic matters studied here, CABs were directly involved by roughly double the margin as faculty governance bodies. And, in a significant minority of FBS schools, CABs were not directly accountable to the faculty or its governance body. CABs were standing committees or subcommittees of the faculty governance body at less than half the universities and did not have a voting majority of tenured faculty in one-fifth of them. Nearly a one-quarter of the CABs did not have at least one faculty member elected or appointed by the faculty governance body.

COIA's longstanding position is that there is no one correct way for universities to align the responsibilities of the FAR, CAB, and the faculty governance body. The structures and traditions of intercollegiate athletic programs vary from campus to campus and, therefore, the distribution of responsibilities for faculty oversight should vary commensurately. Reporting the percentages of those that have adopted COIA best practices is a means by which FBS schools can benchmark their prac- 
tices with those of their peers. And, in turn, such comparisons may be fodder for local discussions about the proper role of the faculty and how best to protect the academic integrity in intercollegiate athletics at their universities.

However, even with increased faculty involvement in academic oversight of intercollegiate athletics, the prospects of preventing further deterioration of athletic-academic integration-let alone reinvigorating it — are not great. Too many forces are at play, and most are far beyond the control of university faculties. But studying difficult_-sometimes seemingly unsolvable-problems and searching for solutions are what faculty are trained to do and do well. Therefore, despite the magnitude of the problem and the long odds against near-term success, faculty should have a significant role in finding and implementing a solution. Moreover, the results of this survey support the conclusion that the faculties at FBS schools have many underutilized tools at their disposal that can assist them in protecting core academic values and standards at universities competing at the highest level of intercollegiate sport. As the late NCAA president Brand concluded, “... academic reform (of intercollegiate athletics) cannot be achieved by any one group in seclusion. Faculty involvement in the implementation of stricter standards-and faculty oversight of the academic integrity of the institution-is a critical piece of the reform puzzle" (Brand, 2005).

\section{Note}

1. The eight tables below mirror the form and content of the survey distributed to FBS institutions. Each table corresponds to one of the eight sections from the survey (i.e., "admissions and recruiting", "academics", "student-athlete integration", etc.). The language employed in the tables is the exact language employed in the survey's items. No items have been omitted. Respondents were given the choice of answering "yes" or "no" and, in a few cases, "not applicable." The percentages and Ns reported below are for "yes" responses.

\section{References}

Brand, M. (2005, February 14). Faculty integral to instilling integrity within academic reform. The NCAA News Online. Retrieved from http://fs.ncaa.org/Docs/NCAANewsArchive/2005/Editorial/faculty+integral+to+instilling+integrity+within+academic+re form+-+2-14-05+ncaa+news.html

Coalition on Intercollegiate Athletics. (2004). Campus Athletics Governance, the Faculty Role: Principles, Proposed Rules, and Guidelines. Retrieved from http://blogs.comm. psu.edu/thecoia/?page_id=182

Coalition on Intercollegiate Athletics. (2007). Framing the Future: Reforming Intercollegiate Athletics. Retrieved from http://blogs.comm.psu.edu/thecoia/?page_id=182

Knight Commission on Intercollegiate Athletics. (October 2009). Quantitative and Qualitative Research with Football Bowl Subdivision University Presidents on the Costs and Financing of Intercollegiate Athletics: Report of Findings and Implications. Retrieved from http://www.knightcommissionmedia.org/images/President_Survey_FINAL.pdf

Lawrence, J.H., Henricks. L.A., \& Ott, M. (2007, October 15). Faculty Perceptions of Intercollegiate Athletics Survey. Washington, D.C.: Knight Commission on Intercollegiate Athletics.

Sander, L. (2010, June 23). Pledges From the NCAA President-Elect. The Chronicle of Higher Education. Retrieved from http://chronicle.com/blogs/players/pledges-fromthe-ncaa-president-elect/25040 